\title{
Impact of working capital management on profitability: Evidence from Pakistan oil sector
}

\author{
M. Yousaf Raza (Corresponding author) \\ Lecturer Department of Management Sciences Mohi ud din Islamic University Islamabad \\ Pakistan
}

Email: Yousaf.raza@ymail.com, Yousaf.raza@miu.edu.pk

Muhammad Bashir

Govt College University Faisalabad Pakistan

\begin{abstract}
Khalid Latif
Lecturer Department of Management Sciences Mohi ud din Islamic University Islamabad Pakistan
\end{abstract}

Touqeer Sultan Shah

Lecturer Department of Management Sciences Mohi ud din Islamic University Islamabad Pakistan

Mushtaq Ahmed

Accepted: June 12, 2015

DOI: 10.5296/ijafr.v5i1.7825 URL: http://dx.doi.org/10.5296/ ijafr.v5i1.7825

\begin{abstract}
This study explores the impact of working capital management on the profitability of the firms in the oil sector of Pakistan. For the purpose of testing this relationship data from the annual reports of the sample companies is used from the period 2006 to 2010. Cash conversion cycles (CCC), average receivable, Average inventory, average payable, and current ratio are used as a measure of working capital management, while gross operating profit is used as a measure of profitability of the firm. There are three major issues in




\section{MInstitute Mach $^{m}$}

International Journal of Accounting and Financial Reporting ISSN 2162-3082

financial management that are capital budgeting, capital structure, and working capital management. So working capital management is one of the three major issues in financial management. A commercial firm consists of two types of assets, which are fixed assets and current assets. Current assets of a firm consist of cash, bank balance, account receivable, raw material, work in process, and finished goods. While fixed assets of the business require capital expenditure and these are used in increasing the production of the business, the Current assets are used in utilizing the fixed assets in day to day transactions. Hence Current assets are regarded as lifeblood for any business firm, the play vital role in the daily operations of the business. Current assets and current liabilities regarded as are very important component of total assets and they need to be carefully managed for the long term success of the business. In this paper working capital management provide us profit by using average payable and gross operating profit but other variables in hypothesis shows negative relationships with each other.

Keywords: Working Capital Management, Profitability, Profitability Ratios

\section{Introduction}

Working capital management is defined as, the administration of the firm's current assets and the financing needs to support current assets. The current assets of a typical manufacturing firm accounts for more than half of its total assets, and for a distribution company, they account for even more. Maintaining excessive levels of current assets can easily result in a firm's realizing a substandard return on investment. However firms with too few current assets may run the risk of shortages and difficulties in maintaining smooth operations(Wachowicz 2001). "There are two major concept of working capital; net working capital and gross working capital. Accountants define the term working capital as net working capital which is the difference between current assets and current liabilities; however this concept makes little difference because the concept is continuously changing.

Financial analysts define working capital as the sum of total current assets, i.e. there focus is on gross working capital. A financial manager is involved in providing the correct amount of current assets for the firm at all the time. Working capital management involves not only the administration of the firm's current assets i.e. cash, marketable securities, receivables, and inventory but also the financing needs to support them" (Jain, 2004). According to Eljelly (2004), working capital management is the process of planning and controlling the current assets and current liabilities of the business in such a way that eliminates the risk of inability to meet due the short term obligations of the business, and at the same time avoid excessive investment in the current assets. According to Filbeck and Krueger (2005), maintaining an optimal balance among all working capital components is the major objective of working capital management. The success of any business depends quite heavily on the ability of financial management to effectively and efficiently manage the working capital that is receivables, inventory, and payables.

According to (Damodaran 2003) investment in working capital management needs tradeoff between the various factors of the firms, as an increased level of working capital has negative 


\section{Mll Macrothink}

International Journal of Accounting and Financial Reporting ISSN 2162-3082 2015, Vol. 5, No. 1

effect on the cash flows at the same time liquidity of the firm is increased which results in a reduced liquidity risk. In short the investment in working capital affects the value of the firm; working capital investment strategy must be followed by a cost and benefit analysis so that the benefit of the adopted strategy should exceed its cost. (Raheman and Nasr 2007) suggested that if the firms properly manage their cash, accounts receivables, and inventories this will ultimately help firms to increase their profitability. According to Ricci and Vito (2000), the purpose of working capital management is to manage the firm's current accounts so as to attain a desired balance between profitability and risk. (Nazir and Afza 2009) suggested that firms must maintain an optimal level of working capital, if the working capital is low the company can miss several profitable investment opportunities or suffer short-term liquidity crisis, on the other hand when working capital management is allocated more than required, it renders the management inefficient and reduces the benefits of short-term investments.

(Tauringana and Adjapong Afrifa 2013) suggested that the companies should focus on working capital management so as to increase their profitability by seriously and professionally considering the issues on their cash conversion cycle, which is derived from the number of day's accounts receivable, the number of days of inventories, and the number of days accounts payable. According to Deloof (2003) a popular measure of Working Capital Management is the cash conversion cycle. Cash conversion cycle is the time interval from the expenditure for the purchases of raw materials till the collection of cash resulting from the sales of finished goods. The longer this time interval, the larger will be the investment in working capital. He also suggested that by reducing the number of days account receivable and inventory turnover the manager can create value for the share holders.

The issue of working capital management traditionally measured by the components such as, average receivable period, average inventory period, average payable period, cash conversion cycle (CCC), and current ratio has remained continuously under the discussion in the field of financial management because of its increasing importance in the long term success of the firms. The focus of this research is to study the impact of working capital management on profitability of Pakistani firms listed at Karachi stock exchange (KSE) from the oil Sector. Hence the problem statement of our research is: "Impact of working capital management on profitability: Evidence from Pakistan".

\section{Literature Review}

(Gill, Biger et al. 2010) examined the relationship between Working Capital management and profitability in USA. They selected a sample of 88 firms listed at New York stock exchange for a period of three years from 2005 to 2007.they used Cash conversion cycle as a proxy for working capital management while gross operating profit as a measure of profitability. Using correlation and regression model they found statistically significant positive relationship between cash conversion cycle and profitability. (Ding, Guariglia et al. 2013) examined the Relationship between working capital management and profitability in Vietnam for a sample of 130 stock listed firms for the period 2006 to 2008. After applying correlation and multiple regression models they found a strong negative relationship between measures of working capital management including the number of days accounts receivable, number of days inventories and cash conversion cycle with corporate profitability, gross operating profit 


\section{Mll Macrothink}

International Journal of Accounting and Financial Reporting ISSN 2162-3082 2015, Vol. 5, No. 1

was used as a measure of profitability. They also found positive relationship between number of days account payable and profitability. Karduman, Akbas, Ozsozgun, and Durer (2010) investigated the effects of working capital management on profitability for a sample of 140 companies listed at Istanbul stock exchange and for a period of 4 years from 2005 to 2008 . Number of days account receivable, Number of days of inventory, Number of day's accounts payable, and cash conversion cycle were used as a measure of working capital management while return on assets was used as a measure of profitability. Using correlation and regression model they found statistically significant negative relationship between measures of working capital management and profitability.

(Mathuva 2009) investigated the influence of working capital management on corporate profitability for a sample of 30 firms listed at Nairobi stock exchange for the period 1993 to 2008. They applied pooled OLS and fixed effect regression model, their findings suggested statistically significant negative relationship between accounts collection period and profitability, and they also found statistically significant negative relationship of profitability measured through net operating profit with average payment periods and inventory conversion period. (Raheman and Nasr 2007) examined the relationship between working capital management and profitability for a sample of 94 Pakistani firms listed on Karachi Stock Exchange for a period of 6 years from 1999 to 2004. They studied the effect of different variables of working capital management including the Average collection period, Inventory turnover in days, Average payment period, Cash conversion cycle and Current ratio on the Net operating profitability of the firms. By using Pearson's correlation and regression model they found a strong negative relationship between measures of working capital management and profitability. (Pouraghajan and Emamgholipourarchi 2012) investigated the relationship between working capital management and profitability for a sample of 3 firms from petrochemical industry for a period of 5 years from 2004 to 2009. Average collection period, inventory turnover in days, average payment period, cash conversion cycle (CCC), and current ratio were used as a measure of working capital management, and there effect was studied on gross operating profitability, a measure of firms profitability. Result of Pearson correlation and linear regression showed a strong negative relationship between variables of working capital management and profitability. (Nazir and Afza 2009) examined the impact of aggressive working capital management policy on firm's profitability for a sample of 204 non-financial firms listed at Karachi Stock Exchange (KSE) for the period 1998-2005. The study used return on asset and Tobin's q as a measure of profitability and panel data regression model was applied to test the relationship. The result of the study suggested negative relationship between the profitability of firms and degree of aggressiveness of working capital investment and financing policies. Deloof 2003) examined the relationship between working capital management and profitability for a sample of 1009 Belgium firms for the period 1992 to 1996 . He used cash conversion cycle a measure of working capital management and gross operating income as a measure of profitability. the result of statistical tests of regression and correlation suggested a significant inverse relationship between cash conversion cycle and gross operating profit. Lazaridis and Tryfonidis (2006) investigated the relationship between working capital management and corporate profitability for a sample of 131 companies listed at Athens Stock Exchange for the 


\section{N Macrothink}

International Journal of Accounting and Financial Reporting

ISSN 2162-3082

2015, Vol. 5, No. 1

period 2001 to 2004 . The result from correlation and regression analysis indicated that there was a statistical significant negative relationship between profitability, measured through gross operating profit, and working capital management, measured through cash conversion cycle. From those results, they suggested that the managers could create value for shareholders by handling correctly the cash conversion cycle and keeping each different component to an optimum level.

\section{Theoretical Framework}

Fig1.

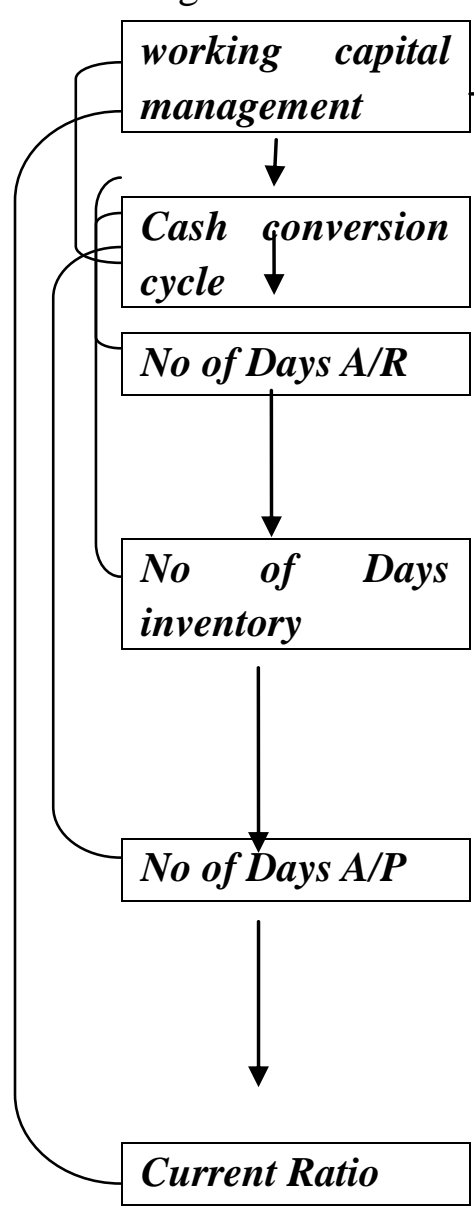

Gross profit Ratio

\section{Working capital management:}

The objective of this study is to investigate the impact of working capital management on the profitability of the firms. Cash conversion cycles (CCC) and current ratio are used as a measure of working capital management, while gross operating profit is used as a measure of profitability of the firm. Cash conversion cycle has further three components which are described below:

Cash Conversion Cycle $=$ No of Days A/R + No of Days Inventory - No of Days A/P

No of Days $A / R=$ Accounts Receivables/Sales*365 


\section{Macrothink \\ International Journal of Accounting and Financial Reporting

No of Days Inventory = Inventory/Cost of Goods Sold $* 365$

No of Days A/P = Accounts Payables/Cost of Goods Sold $* 365$

\section{Current ratio}

Current ratio is obtained by simply dividing current assets by current liabilities.

\section{Current Ratio $=$ Current assets $/$ current liabilities}

\section{Profitability}

Profitability our dependent variable in this study is measured through gross operating profit as,

\section{Gross Profit Ratio $=($ Sales - COGS $) /$ Sales}

The reason for using gross operating profit instead of earnings before interest and taxes (EBIT) or profits before or after taxes is because we want to associate operating 'success' or 'failure' with an operating ratio and relate this variable with other operating variables (i.e. cash conversion cycle) and current ratio. We also want to exclude the participation of any financial activity from operational activity that have the potential to affect overall profitability of the firm, thus we subtracted financial assets from total assets.

\section{Control variables}

Three variables are used as control variables in this study these variables are size of the firm (measured in terms of natural log of sales), debt ratio (debt to total asset), and GDP growth rate of the country.

Firm Size $=$ Natural Logarithm of Sales

Financial Debt Ratio $=($ Short-Term Loans + Long-Term Loans $) /$ Total Assets

\section{Hypothesis Development}

Ho: There is no relationship between $\mathrm{CCC}$ and gross operating profit. $\mathrm{H} 1$ : There is a negative relationship between $\mathrm{CCC}$ and gross operating profit.

Ho: There is no relationship between average receivable and gross operating profit.

$\mathrm{H} 2$ : There is negative relationship between average receivable and gross operating profit.

H0: There is no relationship between average inventory and gross operating profit.

H3: There is negative relationship between average inventory and gross operating profit.

Ho: There is no relationship between average payable and gross operating profit.

$\mathrm{H} 4$ : There is a positive relationship between average payable and gross operating profit.

\section{Data and Methodology}

This study is aimed at investigating the impact of working capital management on the profitability of the firms in the oil sector of Pakistan. For the purpose of testing this relationship data from the annual reports of the sample companies is used from the period 2006 to 2010. Cash conversion cycles (CCC), average receivable, Average inventory, average payable, and current ratio are used as a measure of working capital management, while gross operating profit is used as a measure of profitability of the firm. 
Oil and Gas Companies Financial Ratios Analysis

Fig 2.

\begin{tabular}{|c|c|c|}
\hline & Oil and Gas Companies Financial Ratios Analysis & Nature of Business \\
\hline & Name of Company & $\begin{array}{l}\text { Oil and Gas Exploration and } \\
\text { Production }\end{array}$ \\
\hline 1 & Oil and Gas Development Company Limited & Oil and Gas marketing \\
\hline 2 & Shell pakistan Limited & $\begin{array}{l}\text { Oil and Gas Exploration and } \\
\text { Production }\end{array}$ \\
\hline 3 & Pakistan Petroleume Limited & Oil and Gas Refining and distribution \\
\hline 4 & Attock Refinery Limited & $\begin{array}{l}\text { Oil and Gas Exploration and } \\
\text { Production }\end{array}$ \\
\hline 5 & Pakistan Oil Fields Limited & \\
\hline & Financial Analysis & Formulas \\
\hline & Ratio & Sales/ Average Trade Debts \\
\hline 1 & Debtors Turnover Ratios & Purchases/AverageTrade creditors \\
\hline 2 & Creditors Turnover Ratio (in days) & Equity/ total equity + liabilities \\
\hline 3 & Equity Ratio & Total profit/ total assets \\
\hline 4 & Return on assets & toal profit/ owners equity \\
\hline 5 & Return on equity & current assets/current liability \\
\hline 6 & Current ratio & Total profit/ total assets \\
\hline 7 & Return on investment & Operating Expenses/Sales \\
\hline 8 & Operating Ratio & Sales-CGS/Sales \\
\hline 9 & Gross Profit Ratio & $\begin{array}{l}\text { Long term } \\
\text { debts/Capital+Reserves+Long term } \\
\text { debt }\end{array}$ \\
\hline 10 & Debt to Equity Ratio & $\begin{array}{l}\text { Average collection period in } \\
\text { days+inventory turnover in } \\
\text { days-payable turnover in days }\end{array}$ \\
\hline 11 & Cash Conversion Cycle & $\begin{array}{l}\text { Average collection period in } \\
\text { days+inventory turnover in } \\
\text { days-payable turnover in days }\end{array}$ \\
\hline
\end{tabular}

\section{Ratio:}

DTR/No. of days in a year

CTE/ No. of days in a year 


\section{OIL AND GAS DEVELOPMENT COMPANY \\ LIMITED}

Table 1.

\begin{tabular}{|c|c|c|c|c|c|c|}
\hline RATIO ANALYSIS & & & & & & \\
\hline For the Year ended & UOM & 2006 & 2007 & 2008 & 2009 & 2010 \\
\hline Current Ratio & Times & 6.92 & 6.65 & 3.72 & 4.01 & 3.46 \\
\hline $\begin{array}{l}\text { Return on assets/ assets turnover } \\
\text { ratio }\end{array}$ & $\%$ & $77 \%$ & $76 \%$ & $87 \%$ & $79 \%$ & $70 \%$ \\
\hline Return on equity (average) & $\%$ & $48 \%$ & $43 \%$ & $41 \%$ & $47 \%$ & $42 \%$ \\
\hline $\begin{array}{l}\text { Return on investment (ROI) /return } \\
\text { on assets }\end{array}$ & $\%$ & $36 \%$ & $34 \%$ & $31 \%$ & $34 \%$ & $29 \%$ \\
\hline Receviable turnover (in days) & Days & 81 & 95 & 100 & 135 & 178 \\
\hline Payable turnover (in days) & Days & 110 & 81 & 107 & 126 & 151 \\
\hline Inventory turnover (in days) & $\begin{array}{l}\text { not applicable as } \\
\text { the value of } \\
\text { closing stock is } \\
\text { marginal and } \\
\text { not measured } \\
\text { with respect to } \\
\text { cost of goods } \\
\text { sold }\end{array}$ & & & & & \\
\hline Operating Ratio & $\%$ & 28.5 & 31 & 30.6 & 30.1 & 29.3 \\
\hline Gross Profit Ratio & $\%$ & 71.5 & 69 & 69.4 & 69.9 & 70.7 \\
\hline Debt to equity Ratio & Times & $0 / 1$ & $0 / 1$ & $0 / 1$ & $0 / 1$ & $0 / 1$ \\
\hline Cash Conversion Cycle & in days & (28.39) & 13.94 & (7.63) & 8.84 & 27.01 \\
\hline Note: In operating ratio the & Royalty Operat & ng and & & & & \\
\hline
\end{tabular}


transportation charges are taken

Note: Company has not long term debts

\section{SHELL PAKISTAN LIMITED}

Table 2.

\section{RATIO ANALYSIS}

$\begin{array}{llllll}\text { UOM } & 2006 & 2007 & 2008 & 2009 & 2010\end{array}$

For the Year ended

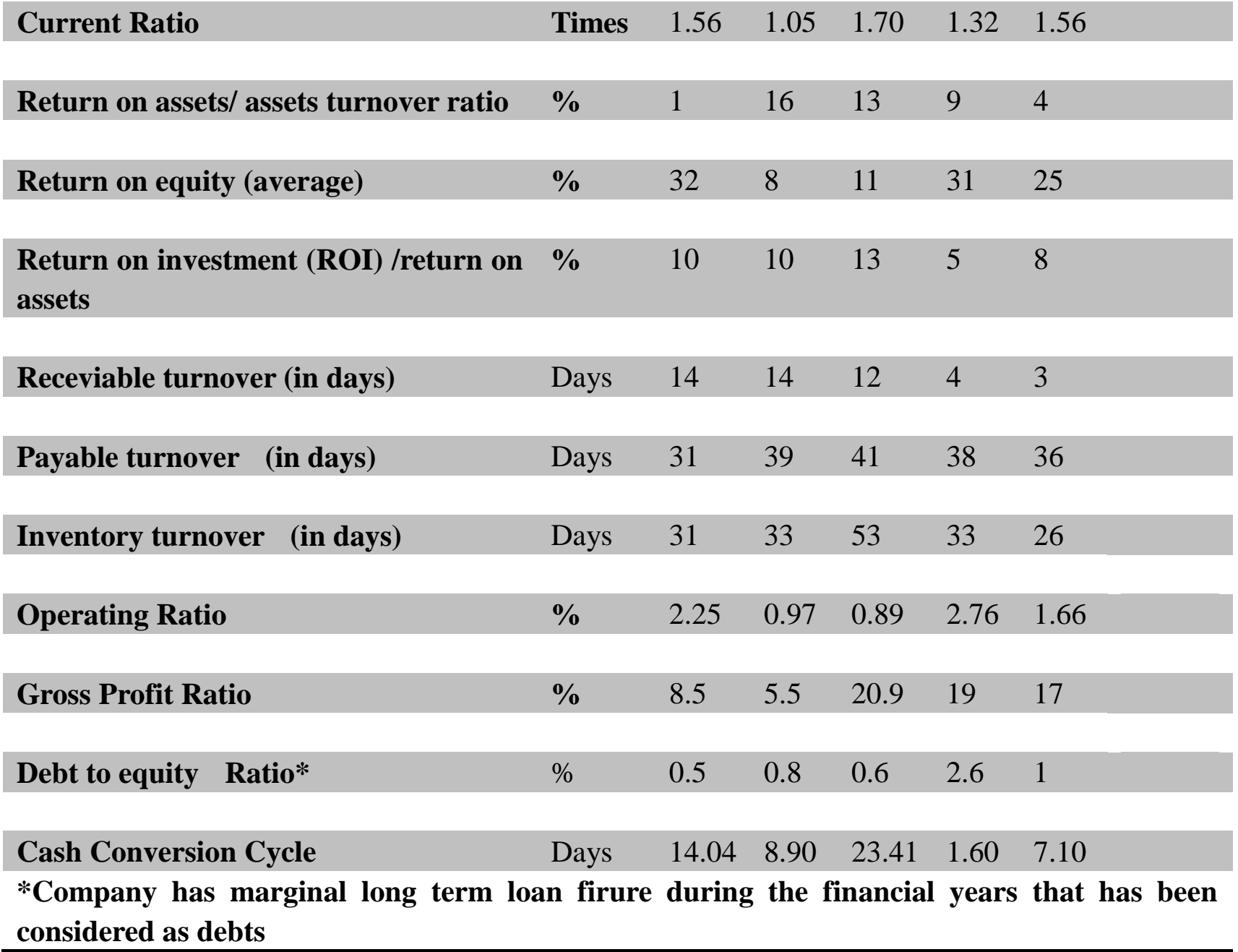




\section{PAKISTAN}

\section{PETROLEUM}

\section{LIMITED}

Table 3.

\begin{tabular}{|c|c|c|c|c|c|c|}
\hline \multicolumn{7}{|l|}{ RATIO ANALYSIS } \\
\hline For the Year ended & UOM & 2006 & 2007 & 2008 & 2009 & 2010 \\
\hline Current Ratio & Times & 3.25 & 4.35 & 2.79 & 3.10 & 3.21 \\
\hline $\begin{array}{l}\text { Return on assets/ } \\
\text { assets turnover ratio }\end{array}$ & $\%$ & 0.87 & 0.84 & 0.82 & 0.86 & 0.83 \\
\hline $\begin{array}{l}\text { Return on equity } \\
\text { (average) }\end{array}$ & $\%$ & 44 & 42 & 45 & 44 & 29 \\
\hline $\begin{array}{l}\text { Return on investment } \\
\begin{array}{lll}\text { (ROI) /return } & \text { on } \\
\text { assets } & & \end{array}\end{array}$ & $\%$ & 0.87 & 0.84 & 0.82 & 0.86 & 0.83 \\
\hline $\begin{array}{l}\text { Receviable turnover } \\
\text { (in days) }\end{array}$ & days & 66 & 76 & 89 & 122 & 178 \\
\hline $\begin{array}{l}\text { Payable turnover (in } \\
\text { days) }\end{array}$ & days & $\begin{array}{l}\text { not } \\
\text { applicable } \\
\text { in view of } \\
\text { the nature } \\
\text { of the } \\
\text { company's } \\
\text { business }\end{array}$ & & & & \\
\hline $\begin{array}{l}\text { Inventory } \\
\text { (in days) }\end{array}$ & days & $\begin{array}{l}\text { not } \\
\text { applicable } \\
\text { in view of } \\
\text { the nature } \\
\text { of the } \\
\text { company's } \\
\text { business }\end{array}$ & & & & \\
\hline Operating Ratio* & $\%$ & 59 & 62 & 65 & 67 & 58 \\
\hline Gross Profit Ratio & $\%$ & 62 & 64 & 65 & 67 & 58 \\
\hline $\begin{array}{l}\text { Debt to equity } \\
\text { Ratio*** }\end{array}$ & Times & $0 / 1$ & $0 / 1$ & $0 / 1$ & $0 / 1$ & $0 / 1$ \\
\hline $\begin{array}{l}\text { Cash Conversion } \\
\text { Cycle }\end{array}$ & days & 66 & 76 & 89 & 122 & 178 \\
\hline
\end{tabular}




\begin{tabular}{|c|c|c|c|c|c|c|}
\hline \multicolumn{7}{|l|}{ RATIO ANALYSIS } \\
\hline For the Year ended & UOM & 2006 & 2007 & 2008 & 2009 & 2010 \\
\hline Current Ratio & Times & 5.10 & 4.10 & 3.10 & 1.10 & 9.10 \\
\hline Total assets turnover ratio & Times & 5.08 & 3.91 & 4.02 & 2.36 & 2.48 \\
\hline Return on equity (average) & $\%$ & 44 & 42 & 45 & loss & Loss \\
\hline $\begin{array}{l}\text { Return on investment (ROI) /return on } \\
\text { assets }\end{array}$ & $\%$ & 0.87 & 0.84 & 0.82 & 0.86 & 0.83 \\
\hline Receviable turnover (in days) & Days & 22.75 & 26.91 & 27.22 & 56.74 & 72.73 \\
\hline Payable turnover (in days) & Days & 34 & 54 & 50 & 98 & 128 \\
\hline Inventory turnover (in days) & Days & 18.34 & 28.85 & 28.43 & 39.91 & 35.84 \\
\hline Operating Ratio & $\%$ & 2.19 & 2.60 & 9.25 & 4.28 & 0.91 \\
\hline Gross Profit Ratio & $\%$ & 1 & 1.5 & 4.3 & 2.5 & $(0.60)$ \\
\hline Debt to equity Ratio & Times & $0 / 1$ & $0 / 1$ & $0 / 1$ & $0 / 1$ & $48 / 52$ \\
\hline Cash Conversion Cycle & Days & 7.04 & 1.77 & 5.72 & $(1.47)$ & $(19.50)$ \\
\hline
\end{tabular}

\section{PAKISTAN OIL FIELDS}

Table 5.

\begin{tabular}{|c|c|c|c|c|c|c|}
\hline \multicolumn{7}{|l|}{ RATIO ANALYSIS } \\
\hline For the Year ended & UOM & 2006 & 2007 & 2008 & 2009 & 2010 \\
\hline Current Ratio & Times & 2.13 & 4.29 & 4.22 & 3.54 & 3.69 \\
\hline Total assets turnover ratio & Times & 0.75 & 0.59 & 0.57 & 0.42 & 0.48 \\
\hline Return on equity (average) & $\%$ & 42 & 30.13 & 33.95 & 21.66 & 25.53 \\
\hline $\begin{array}{l}\text { Return on investment (ROI) } \\
\text { /return on assets }\end{array}$ & $\%$ & 0.87 & 35 & 38 & 22 & 27 \\
\hline $\begin{array}{l}\text { Receviable turnover (in } \\
\text { days) }\end{array}$ & days & 44.51 & 61.97 & 45.17 & 47.10 & 45.12 \\
\hline Payable turnover (in days) & days & $\begin{array}{l}\text { not applicable in } \\
\text { view of the } \\
\text { companied business }\end{array}$ & & & & \\
\hline $\begin{array}{l}\text { Inventory turnover } \\
\text { days) }\end{array}$ & days & $\begin{array}{l}\text { not applicable in } \\
\text { view of the } \\
\text { companied business }\end{array}$ & & & & \\
\hline Operating Ratio & $\%$ & 56.48 & 54.05 & 58.92 & 51.15 & 53.75 \\
\hline Gross Profit Ratio & $\%$ & 66.59 & 60.05 & 63.22 & 59.03 & 61 \\
\hline Debt to equity Ratio & Times & $0 / 1$ & $15 / 59$ & $0 / 1$ & $0 / 1$ & $0 / 1$ \\
\hline Cash Conversion Cycle & & 44.51 & 61.97 & 45.17 & 47.10 & 45.12 \\
\hline
\end{tabular}




\section{Results and Discussion}

The measure for firm-level performance was selected as the 5-year average return on assets of oil sectors in Pakistan. Industrial organization economics has proven extremely useful to researchers of strategy content in providing a basic theoretical perspective on the influence of capital structure on firm strategy and performance. While there is a range of specific model and the major determinants of firms include assets turn over, return on equity (average), ROI, receivable, payable turnover, inventory turnover, operating, debt to equity and cash conversion cycle. These determinants have direct relationship with working capital management and profitability. Our economic model includes several of the explanatory variables such as management of working capital and profitability of firms. This study is based on secondary source data of firms. Climate is not structure-size, production processes, arrangements. Structure may influence capital, but it is necessary to examine structure of industries to describe an organization's structure.

Additionally, the same structures in different organizations may produce very different results, as structure is only one of the many factors that significantly influence the demand and organizational equipments. Oil and gas Development Company limited has an efficient current ratio from 2006-2010, while ROE, ROI and ROA are efficient in 2066, 2007, 2008 and 2009 but decreased in 2010. Receivable and payable in days was good in each year. The turnover inventory in days not applicable as the value of closing stock is marginal and not measured with respect to cost of goods sold. Operating ratio, gross profit ratio and are measured in percentage, their values increased each year and debt ratio and cost conversion ratio also changes from year to year towards success. Shell Pakistan limited has an efficient current ratio from 2006-2010, while ROE, ROI and ROA are efficient in 2005, 2008 and 2010 but decreased in 2006, 2007. Receivable and payable in days was good in 2006, 2009, 2010 and low in other years. The turnover inventory in days is not efficient in 2010 but other year's shows good results. Operating ratio, gross profit ratio and are measured in percentage, their values increased each year and debt ratio and cost conversion ratio also changes from year to year towards success. Pakistan petroleum limited has an efficient current ratio from 2006-2010, while ROE, ROI and ROA are efficient in 2006, 2007 and 2009 but decreased in 2005, 2008 and 2010. Receivable remained good each year but payable in days was not applicable in view of the nature of the company's business. The turnover inventory in days is not applicable in view of the nature of the company's business. Operating ratio, gross profit ratio and are measured in percentage, their values increased each year but not good in 2010, and debt ratio and cost conversion ratio also changes from year to year towards success but not good in 2010 .

\section{Data and Measures}

The sample includes 05 oil and gas sector companies working in Pakistan representing both working capital and profitability of these firms. The sample clearly represents the major ratios that we have calculated. 


\section{Ml Macrothink}

International Journal of Accounting and Financial Reporting

ISSN 2162-3082

2015, Vol. 5, No. 1

\section{Conclusion}

Results of the study will be useful for the higher management of the organizations to understand how they can perform better to develop their organizational performance where employees can better execute for their selves and for the firms. We examined and find that firm's profitability perceptions fluctuate significantly during the crisis, with risk tolerance and risk perceptions being less volatile than return expectations. This study shows the firm's efficiency w.r.t return, return expectations and current assets. Such studies can easily change and can provide optimistic results for future profitability of firms.

\section{Future Work}

This research is not only limited to Pakistan only; but environment can make their investments well by using international methods. We can make our study more efficient if we judge and contrast with other environmental factors.

\section{References}

Damodaran, A. (2003). Investment philosophies: successful strategies and the investors who made them work, John Wiley \& Sons.

Ding, S., A. Guariglia, et al. (2013). "Investment and financing constraints in China: does working capital management make a difference?" Journal of Banking \& Finance 37(5): 1490-1507.

Deloof, M. 2003. "Does Working Capital Management Affects Profitability of Belgian Firms?", Journal of Business Finance \& Accounting, Vol. 30 No 3 \& 4 pp. $573-587$

Eljelly, A. M. A. (2004). Liquidity-Profitability Tradeoff: An Empirical Investigation in an Emerging Market. International Journal of Commerce and Management, 14 (2), 48-61.

Filbeck G and Krueger T (2005), "Industry Related Differences in Working Capital Management", Mid-American Journal of Business, Vol. 20, No. 2, pp. 11-18.

Gill, A., N. Biger, et al. (2010). "The relationship between working capital management and profitability: Evidence from the United States." Business and Economics Journal 10(1): 1-9.

Jain, N.K. (2004). Working capital management. A.P.H. Publishing Corporation, New Delhi.

Lazaridis, I., \& Tryfonidis, D. (2006). Relationship between working capital management and profitability of listed companies in the Athens stock exchange. Journal of Financial

Management and Analysis, 19(1), 26-35.

Mathuva, D. (2009). "The influence of working capital management components on corporate profitability: a survey on Kenyan listed firms." Research Journal of Business Management 3(1): 1-11.

Nazir, M. S. and T. Afza (2009). "Impact of aggressive working capital management policy on firms' profitability."

Pouraghajan, A. and M. Emamgholipourarchi (2012). "Impact of Working Capital Management on Profitability and Market Evaluation: Evidence from Tehran Stock Exchange." International Journal of Business and Social Science 3(10): 311-318. 


\section{Macrothink}

International Journal of Accounting and Financial Reporting

ISSN 2162-3082

Ricci, Cecilia and Nino Di Vito (2000), "International Working Capital Practices in the UK",

European Financial Management, Vol. 6, Issue 1, pp. 69-84.

Raheman, A. and M. Nasr (2007). "Working capital management and profitability-case of Pakistani firms." International review of business research papers 3(1): 279-300.

Tauringana, V. and G. Adjapong Afrifa (2013). "The relative importance of working capital management and its components to SMEs' profitability." Journal of Small Business and Enterprise Development 20(3): 453-469.

Van Horne, J. C., \& Wachowicz, J. M. (2004). Fundamentals of Financial Management,12th Edition. Prentice Hall publisher, New York.

Wachowicz, M. (2001). "An approach for developing a knowledge construction process based on the integration of GVis and KDD methods." Geographic data mining and knowledge discovery: 254. 